\title{
Ensino por investigação: concepções dos alunos de licenciatura em Ciências da Natureza acerca da importância de atividades investigativas em espaços não formais ${ }^{1}$
}

\begin{abstract}
Resumo
O presente artigo discute as concepções de um grupo de futuros professores de Ciências da Natureza, extraídas a partir da realização de uma aula em um espaço não formal de ensino, em uma visita guiada ao Delta do Parnaíba - PI. As atividades propostas foram realizadas sob a luz do ensino por investigação, tendo como aporte os construtos da teoria sociointeracionista de Vygotsky. A metodologia empregada é de cunho qualitativo e teve como intuito a coleta de dados que pudessem conduzir a uma imersão nos valores que estão sendo adquiridos sobre a docência por estes alunos. Os resultados demonstram o perfil do processo de construção identitária em relação aos seus saberes docentes.
\end{abstract}

Palavras-chave: Ensino por Investigação; Espaços Não Formais; Formação Inicial Docente; Saberes Docentes.

\author{
Maria das Graças Cleophas \\ Universidade Federal da \\ Integração Latino-Americana - \\ UNILA - PR/Brasil \\ mgcp76@gmail.com
}

\section{Para citar este artigo:}

CLEOPHAS, Maria das Graças. Ensino por investigação: concepções dos alunos de licenciatura em Ciências da Natureza acerca da importância de atividades investigativas em espaços não formais. Revista Linhas. Florianópolis, v. 17, n. 34, p. 266-298, maio/ago. 2016.

\section{DOI: $10.5965 / 1984723817342016266$}

http://dx.doi.org/10.5965/1984723817342016266

\footnotetext{
${ }^{1}$ A autora agradece o apoio dado pela FAPEPI (Fundação de Amparo à Pesquisa do Estado do Piauí).
} 


\title{
Education for research: conceptions
} of degree students in natural sciences about investigative activities importance of spaces nonformal

\begin{abstract}
This article discusses the views of a future teachers group of natural sciences, extracted from a class did in a non-formal teaching space, a guided tour through the "Delta do Parnaíba - PI". The proposed activities were done in the light of learning by requiring, with Vygotsky social of interaction theoretical support. Methodology was a qualitative one and wished to collect data that could lead us to get a such deep approach on the values that has been got on teaching by these students. The results show the profile of the process of identity building regarding their teaching knowhow.

Keywords: Education by Requiring; Non-Formal Spaces; Starting Teacher Training; Teaching Knowhow.
\end{abstract}




\section{Introdução}

Este artigo tem como objetivo discutir as concepções de um grupo de professores em formação inicial em Ciências da Natureza acerca da importância do ensino por investigação e como este pode beneficiar as atividades de campo. Para tanto, trinta alunos $(n=30)$ de um curso de licenciatura em Ciências da Natureza vivenciaram uma experiência didático-pedagógica em um espaço não formal de ensino, por meio de uma visita ao Delta do Parnaíba - Pl, distante 857 km da cidade de origem destes discentes.

O que se propôs nesta pesquisa foi uma sistemática dinamização sobre a atividade de campo planejada, apresentando inúmeras ações ao grupo de estudantes, os quais estavam sendo atores principais de seu próprio aprendizado e, desta forma, assimilando, concomitantemente, possibilidades de aprender a contextualizar e interdisciplinarizar o ensino das Ciências. Acredita-se que, a partir de uma aula de campo, é possível utilizar-se de diversas situações didáticas que podem contribuir para a formação do aluno (futuro professor), pois promovem a contextualização e a interdisciplinaridade, subsidiando, assim, o aprendizado de conceitos científicos de modo versátil e interessante. Nesta perspectiva, Lück (1995, p. 30) afirma que a "interdisciplinaridade não deve ser vista como uma disciplina isolada e sim como concepção orientadora", e isto foi priorizado durante a atividade.

As atividades de campo ainda não possuem um conceito generalizado cientificamente. Para Fernandes (2007), a aula de campo é como uma espécie de visita monitorada, tal como as que ocorrem em instituições de educação não formal, como os museus de ciência e tecnologia, planetários, parques e reservas ambientais, etc. O que se sabe é que as aulas de campo representam excelentes oportunidades para que alunos coloquem em prática os conhecimentos já adquiridos, porém, poucas vezes assimilados de modo correto e em geral distantes de aspectos contextualizadores.

[...] atividade extra sala/extra escola que envolve, concomitantemente, conteúdos escolares, científicos (ou não) e sociais com a mobilidade espacial; realidade social e seu complexo amalgamado material e imaterial de tradições/novidades. (OLIVEIRA e ASSIS, 2009, p. 198) 
Uma aula de campo tem elementos que a distanciam do espaço formal e a tornam inerente à educação não formal de ensino. Decerto, definir um espaço não formal de educação é algo complexo. Para Jacobucci (2008), o espaço não formal de ensino (ou de Educação) é todo aquele em que pode ocorrer uma prática educativa. Em suas pesquisas, Rocha e Fachín-Terán (2010) discutem a importância dos espaços não formais para o ensino de Ciências, e destacam a relevância da escola nesse processo, bem como pontuam a impossibilidade de se alcançar uma educação científica sem a parceria da escola com estes espaços. Sem dúvida, esta deve ser uma condição vital para nortear as atividades nestes espaços, pois, para que uma atividade possa ser benéfica em relação ao aprendizado do aluno, ele deve ter consigo algumas aprendizagens já previamente arraigadas sobre determinados conteúdos, para que ele possa confrontar os conhecimentos adquiridos em sala de aula durante a atividade em espaço não formal porém, nada lhe impede que novos conhecimentos possam ser descobertos e internalizados.

Neste caminho, acredita-se que uma atividade em espaços não formais deve ocorrer como meio de fortalecer o aprendizado do aluno, dando a ele a oportunidade de se conectar cognitivamente a uma teoria já conhecida, porém, muitas vezes assimilada erroneamente, devido ao elevado grau de abstração apresentado, além da falta de analogias que possam ser utilizadas para aplicação dela em sua vida cotidiana. No entanto, é importante destacar que as atividades didáticas realizadas em espaços não formais requerem um preparo muito mais apurado do professor, pois cabe a ele planejar e conduzir os processos que medeiam as condições necessárias ao aprendizado do aluno. Assim, ele precisa estar pronto para responder a diferentes perguntas e questões que emergirão, por parte dos alunos, sobre o novo ambiente que se revela. Logo, para formar um futuro professor, é preciso ensiná-lo, sobretudo, a depurar o seu olhar em relação ao seu entorno, de forma a estabelecer "vínculos de ensino" que possam propiciar um aprendizado respaldado na própria contextualização do sujeito aprendiz perante uma nova situação, bem como na possibilidade de ele reconhecer a importância da utilização de diferentes ambientes para propor estratégias didáticas pautadas na contextualização e na interdisciplinaridade. Para que isso ocorra, Behrens (2009 apud TOBALDINI e FERRAZ, 2011, p. 3) afirma que é “necessário modificar a estrutura paradigmática 
conservadora envolvida na formação dos professores por uma abordagem inovadora de ensino".

Partindo desta perspectiva inovadora, o foco de análise desta pesquisa consistiu em verificar algumas concepções de discentes de um curso de licenciatura sobre uma atividade investigativa que ocorreu em um espaço não formal de ensino, no qual estavam em foco duas situações distintas. A primeira dizia respeito à promoção de uma atividade didática que permitisse colocar em prática a contextualização e a interdisciplinaridade entre os conteúdos ministrados perante o componente curricular "Fundamentos da Química II", disciplina obrigatória do curso de licenciatura em Ciências da Natureza, campus São Raimundo Nonato (PI); e a segunda, ao fato de estes alunos estarem em processo de formação inicial, sendo fundamental agregar saberes docentes necessários para uma boa atuação docente. De um lado, era imprescindível adotar um viés investigativo que pudesse contribuir com a formação destes alunos, possibilitando, assim, situações para o aprendizado ou fortalecimento de conceitos a partir de sua interação com o meio ambiente e com os demais alunos. E, por fim, caracterizar elementos dessa interação, que pudessem conduzir a uma ligação entre o conteúdo dado em sala e as diversas formas de atrelá-lo ao cenário natural do Delta do Parnaíba - PI. Dessa maneira, o que se propõe neste trabalho é o enlace entre a proposta didático-pedagógica baseada na teoria sociointeracionista de Vygotsky, o ensino por investigação e sua aplicação em espaços não formais de educação, verificando, assim, analisar como algumas concepções (dos futuros professores de Ciências) se delinearam perante a referida situação proposta.

\section{O ensino por investigação}

O ensino de Ciências é um campo em que várias vertentes de estratégias didáticas podem coexistir, visando à resolução de problemas. Entre elas, está o ensino por investigação. Este tipo de ensino, quando disposto aos alunos, pode apresentar diversas formas de desafios cognitivos e, por conseguinte, resoluções. A ideia central é propiciar condições favoráveis aos alunos para que construam o conhecimento científico, sendo capazes de refletir, questionar, argumentar, interagir etc., mobilizando, assim, distintos conhecimentos, previamente adquiridos na escola ou em sua vida cotidiana, a fim de resolver uma determinada questão ou situação-problema que é imposta por este tipo de 
ensino. Clement et al. (2015) apontam que o "ensino por investigação prevê, dentre outros aspectos, uma participação ativa do estudante no processo de ensino e aprendizagem, o que Ihes atribui maior controle sobre a sua própria aprendizagem" (p. 117). Isto posto, cabe ao aluno propor soluções, em conjunto com os demais alunos, para resolver as diferentes situações-problemas que são inseridas na atividade. Para Pozo e Pérez Echeverria (1994), a resolução de problemas estimula nos alunos o conhecimento de procedimentos para dar respostas a situações distintas e mutáveis, isto é, desenvolve a verdadeira compreensão dos fatos.

A expansão desse tipo de ensino é notória e se corrobora pelo crescente número de investigadores que discutem e defendem o ensino por investigação, no qual se deve partir de um problema, almejando promover o raciocínio e as habilidades cognitivas dos alunos, além de possibilitar a cooperação entre os estudantes (BORGES, 2002; CARVALHO, 2006; JIMÉNEZ-ALEIXANDRE e FERNÁNDEZ-LÓPEZ, 2010; TROPIA, 2009; CLEMENT et al., 2015, entre outros). Neste sentido, Maldaner (2006) salienta que a existência de um espaço adequado, tal qual um laboratório, é condição necessária, mas não suficiente para uma boa proposta perante o ensino de Química, pois podemos proporcionar atividades experimentais, com viés investigativo, em espaços não formais. Seguindo este pressuposto, é possível promover inúmeras situações-problemas, envolvendo a experimentação em espaços não formais, tendo como aporte o ensino por investigação.

Destarte, para que o ensino de Química não seja limitado a um caráter superficial, mecânico e repetitivo, é essencial que as atividades práticas não fiquem restritas apenas aos procedimentos experimentais, mas permitam momentos de estudo, reflexão e discussão teórica e prática (BRASIL, 2006). Deste modo, acredita-se que o ensino por investigação em espaços não formais possui um elevado potencial para permitir tais situações. Tal pensamento coaduna com o de Demo (2007), pois é preciso combater aulas que ensinem apenas a copiar e não a desenvolver a capacidade de aprender. De um modo geral, cabe ao professor estimular o aluno a compreender que o seu processo de aprendizado atua como uma espécie de "desafio interno", cabendo a ele (aluno) encontrar as respostas ou resolver as situações-problemas, de modo a superar os desafios impostos. Bachelard (1996) defende que todo conhecimento é produto da 
resposta sobre uma determinada questão. E, neste caso, a resolução de problemas que conduza a uma investigação deve ser fundamentada na ação do aluno (MOREIRA, 1983). Desta forma, num ensino que preze pela investigação, os discentes são postos em situações em que realizam diminutas pesquisas, em que se combinam, simultaneamente, conteúdos conceituais, procedimentais e atitudinais (POZO, 1998).

Gil Perez e Castro (1996) descreveram alguns aspectos da atividade científica que podem ser explorados numa atividade investigativa, tais como:

a) Apresentar situações problemáticas abertas;

b) Favorecer a reflexão dos estudantes sobre a relevância e o possível interesse das situações propostas;

c) Potencializar análises qualitativas, significativas, que ajudem a compreender e acatar as situações planejadas e a formular perguntas operativas sobre o que se busca;

d) Considerar a elaboração de hipóteses como atividade central de investigação científica, sendo este processo capaz de orientar o tratamento das situações e de fazer explícitas as preconcepções dos estudantes;

e) Considerar as análises, com atenção para os resultados (sua interpretação física, confiabilidade etc.), a partir dos conhecimentos disponíveis, das hipóteses manejadas e dos resultados das demais equipes de estudantes;

f) Conceder uma importância especial a memórias científicas que reflitam o trabalho realizado e possam ressaltar o papel da comunicação e do debate na atividade científica;

g) Ressaltar a dimensão coletiva do trabalho científico, por intermédio de grupos de trabalho, que interajam entre si.

Uma das grandes vantagens de se trabalhar com o ensino por investigação, entre outras, está ancorada na perspectiva de interação social entre os sujeitos aprendizes, o que, necessariamente, favorecerá a argumentação entre eles e contribuirá para que a resolução dos problemas seja realizada de modo coletivo, e não individual. Ou seja, “[...] o diálogo, a cooperação e troca de informações mútuas, o confronto de pontos de vista divergentes e que implicam na divisão de tarefas onde cada um tem uma responsabilidade que, somadas, resultarão no alcance de um objetivo comum" (REGO, 1995, p. 110). 
Jimenez-Aleixandre e Fernandez-Lopez (2010) pontuam que o ensino de Ciências por investigação promove o desenvolvimento de processos associados à produção do conhecimento científico, especialmente produção, validação e argumentação. Não obstante, as instituições de ensino formal apresentam, muitas vezes, problemas perante a construção deste conhecimento científico pelos alunos, pois propõem poucas situações que sejam capazes de aproximar as atividades didático-metodológicas do saber científico. Essa afirmativa se aproxima do pensamento de Carvalho (2007), pois a autora mostra que as dificuldades vivenciadas pelas escolas em despertar a curiosidade e o interesse dos alunos na hora da aprendizagem dos conhecimentos científicos acabam prejudicando também o desenvolvimento humano dos alunos. Assim sendo, uma maneira de alterar este quadro seria propor atividades com foco no ensino por investigação e ainda, tal como propõe este trabalho, que elas sejam executadas em espaços não formais, favorecendo determinados fatores de interação entre os indivíduos e que possam, sobretudo, facilitar a construção de conhecimentos científicos.

\section{A interação social como aporte ao ensino por investigação}

Conforme aponta Jorde (2009, apud CARVALHO et al., 2013), o ensino por investigação possui características essenciais, que são responsáveis por envolver os alunos durante uma atividade. São elas: (1) atividades de aprendizagem baseadas em problemas autênticos; (2) experimentação e atividades práticas, incluindo a busca por informações; (3) atividades autorreguladas, ou seja, que priorizem a autonomia dos alunos; e, finalmente, (4) a comunicação e a argumentação. Não se pode excluir do processo de ensino por investigação a comunicação e a argumentação. Estas duas, em conjunto, alicerçam todo o desencadeamento da construção do processo de aprendizado do indivíduo. Doravante, é importante fundamentar as ideias aqui apresentadas, relacionando-as com os estudos propostos por Vygotsky. Para ele, a construção do conhecimento está centrada na construção social do indivíduo. Vygotsky valoriza o papel do professor diante da construção do novo conhecimento, dentro de uma proposta sociointeracionista, considerando-o um elaborador de questões que orientarão seus alunos, potencializando a construção de novos aprendizados (OLIVEIRA et al., 2013). 
Contudo, esta proposta sociointeracionista, em um contexto educacional, não está limitada apenas ao professor e ao aluno, ela assumiria um papel amplo dentro destes “contratos de comunicação" (CHARAUDEAU, 1996, p. 20) que são estabelecidos, de modo que a interação social possa abarcar todo o ambiente em que o aluno se encontra, fazendo-o interagir com toda e qualquer informação que possa estar atrelada aos conteúdos que o professor esteja aplicando em sala de aula e fora dela. Vygotsky (1989) acredita que as características individuais e até mesmo as atitudes individuais estejam impregnadas de trocas com o coletivo, ou seja, mesmo o que se toma por mais individual de um ser humano foi construído a partir de sua relação com outro indivíduo. Vygotsky (1996) estabelece o conceito de algumas zonas de desenvolvimento, e, entre elas, está a Zona de Desenvolvimento Proximal (ZDP). Esta zona é definida como sendo a distância entre o nível de desenvolvimento real (NDR), ou seja, determinado pela capacidade individual que o sujeito tem de resolver um dado problema, e o nível de desenvolvimento potencial (NDP), balizado pela capacidade que este indivíduo possui de interagir socialmente com os outros, de modo colaborativo, visando solucionar problemas. No nível escolar, esta colaboração pode acontecer em conjunto com o professor ou com outros colegas.

No que tange ao nível de desenvolvimento real (NDR), esta é uma zona intrínseca a cada sujeito/indivíduo. Assim, a NDR faz menção a etapas de desenvolvimento já concretizadas, ou seja, que foram realizadas, enquanto o nível de desenvolvimento potencial (NDP) indica o desenvolvimento que poderá ser realizado por meio da coletividade, ou seja, pela interação social. Para Zanella (1995), o nível de desenvolvimento potencial (NDP) é mais importante do que o nível de desenvolvimento real (NDR), pois a NDP consiste em ações coletivas que levam ao desenvolvimento de novas habilidades. Já em relação à Zona de Desenvolvimento Proximal (ZDP), esta se compõe de diversas características, tais como a linguagem, o incentivo à interação social e cultural, bem como aspectos de construção individual e cognitiva. "A Zona de Desenvolvimento Proximal define aquelas funções que ainda não amadureceram, mas que estão em processo de maturação, funções que amadurecerão, mas que estão, presentemente, em estado embrionário" (VYGOTSKY, 1984, p. 84). 
É na ZDP que a aprendizagem poderá ocorrer, pois ela agrupa os conhecimentos prévios que os alunos carregam consigo, mas que ainda não foi possível transformá-los em um aprendizado completo, porém, estes conhecimentos são importantes para a fertilização de ideias que permitam a descoberta de novos conhecimentos. No entanto, para que ocorra tal transformação, as interações sociais entre os sujeitos (professor/alunos) deverão ocorrer mediante a troca de experiências e argumentos entre eles. Ademais, é plausível considerar que o ensino por investigação em espaços não formais dialoga com o conceito dado sobre a ZDP, pois essa afirmativa vai ao encontro da ideia defendida por Wells (1999, p. 133), ou seja, a ZDP seria "qualquer situação na qual, enquanto participam de uma atividade, indivíduos encontram-se no processo de desenvolver o domínio de uma prática ou compreensão de um assunto" (p. 133). A Figura 1 ilustra o conceito de Zona de Desenvolvimento Proximal (ZDP).

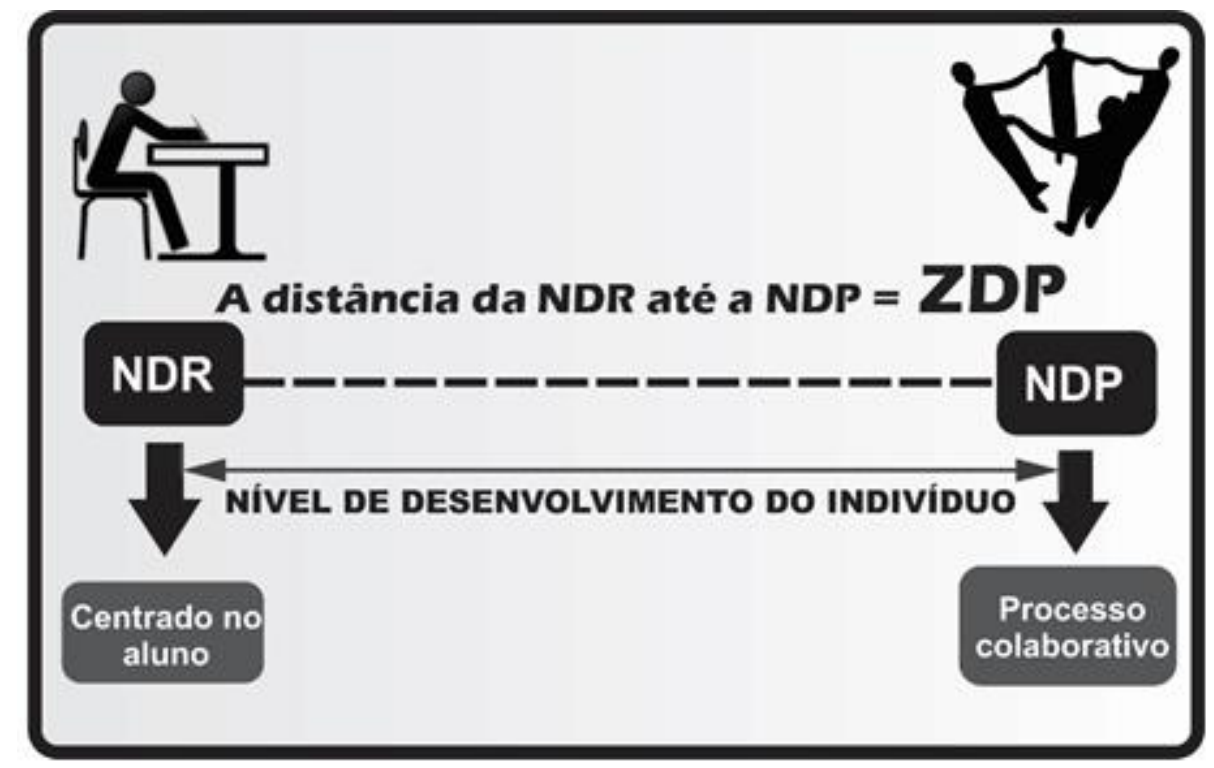

Figura 1: Simbolizando a ZDP.

(Fonte: elaborada pela autora).

Para Vygotsky, o professor é imprescindível para a construção de um novo conhecimento, cabendo a ele planejar as suas ações de modo a adequá-las perante a proposta sociointeracionista, potencializando, desta maneira, novos construtos de conhecimento. Apesar disso, a visão sociointeracionista apresenta algumas implicações para o ensino das Ciências. Por exemplo, para Sasseron e Carvalho (2011), as interações entre os alunos e principalmente entre professor e alunos deveriam levá-los à 
argumentação e à alfabetização científica, porém, a ausência de atividades em espaços não formais que possam promover um ensino por investigação prejudica a construção de saberes científicos de modo contextualizado e impossibilita a argumentação, a resolução de problemas, o levantamento de hipóteses, entre outros fatores.

De acordo com Vygotsky (1982), os professores, ao criarem situações favoráveis à autonomia, garantem um espaço para o confronto de visões, de opiniões, discussões abertas, debates, livre reflexão e de reorganização dos saberes. Xavier e Fernandes (2007) defendem a aprendizagem oferecida em espaços não convencionais da seguinte maneira:

No espaço não convencional da aula, a relação de ensino e aprendizagem não precisa necessariamente ser entre professor e aluno(s), mas entre sujeitos que interagem. Assim, a interatividade pode ser também entre sujeito e objetos concretos ou abstratos, com os quais ele lida em seu cotidiano, resultando dessa relação o conhecimento. (XAVIER e FERNANDES, 2007, p. 226, grifo nosso)

Deste modo, o ensino por investigação realizado em espaços não formais pode representar uma excelente oportunidade para fortalecer as interações entre os indivíduos em formação inicial, possibilitando troca de saberes e/ou apropriação de novos conhecimentos, que, futuramente, poderão ser colocados em sua práxis docente.

\section{A formação inicial de professores: o aluno de hoje, o professor do amanhã}

Aprender a docência requer esforços e comprometimento social. O futuro professor precisa estar consciente do real significado do seu papel, que será desempenhado perante a sociedade, ou seja, é preciso empenho para aprender saberes pedagógicos e, posteriormente, colocá-los em prática durante a atuação como professor, pois a “docência é uma profissão que se constrói cotidianamente" (COUTO, 2009, p. 2). Para Echeverría e Soares (2009), a formação inicial oferecida nas universidades precisa ser repensada e redirecionada, de forma a contribuir para formar um profissional capaz de intervir, criativamente, nas situações complexas da escola. Neste viés, é fundamental que novas ações sejam colocadas em prática durante a formação inicial, de modo a incidir 
mudanças perante esta formação e, consequentemente, promover modificações epistemológicas diante dos processos de ensino e aprendizagem. Azevedo e Abib (2013) defendem que o aprendizado em docência pode ser compreendido como um processo que se dá na relação com o outro, em situações colaborativas, imprescindíveis à apropriação de significados teóricos e metodológicos relativos ao desenvolvimento profissional do professor.

Ainda nesta linha de raciocínio, Tardif (2002, p. 63) elucida que o saber docente é um "saber plural, formado pela amálgama, mais ou menos coerente, de saberes oriundos da formação profissional e de saberes disciplinares, curriculares e experienciais". No que condiz aos saberes experienciais, estes são definidos por Tardif (2012, p. 48) como "um conjunto de saberes atualizados, adquiridos e necessários para o âmbito da prática da profissão docente e que não provém das instituições de formação e nem dos currículos". Entretanto, alguns saberes docentes que são colocados em prática são oriundos de aprendizagens adquiridas ao longo da vida. Para que esses saberes ganhem espaço dentro do cotidiano escolar, é necessário criar situações de aprendizagem que permitam proximidade com a realidade que será vivenciada no âmbito educativo, favorecendo, assim, o estabelecimento de repertórios de conhecimentos distintos, estando estes flexíveis para se adaptarem às mudanças que a práxis docente exige incessantemente.

Neste cenário de mudanças, os saberes necessários ao ensino constituem algo dinâmico e precisam ser constantemente reelaborados e edificados pelos docentes "em confronto com suas experiências práticas, cotidianamente vivenciadas nos contextos escolares" (PIMENTA, 2012, p. 29). A troca de experiência e saberes, não apenas entre professores que estão em atuação, mas entre os alunos que estão em formação inicial, pode contribuir para embasar os saberes indispensáveis à prática do ensino, colaborando com melhorias na qualidade educacional. Desta forma, o surgimento da interação social, através do ensino por investigação, é capaz de flexibilizar diversos saberes oriundos de diferentes fontes de conhecimento. Assim, tal como Shulman (1987), acredita-se ser preciso que os professores possam construir pontes entre o significado do conteúdo curricular e aquele que é compreendido pelos alunos. Em suma, uma formação inicial concebida a partir de um currículo, muitas vezes pouco inovador, onde não são incorporadas em seu planejamento ações didático-pedagógicas para serem 
desencadeadas em espaços não formais, não será capaz de contribuir significantemente com a construção de saberes docentes necessários à prática profissional do futuro professor.

\section{Percurso metodológico}

O presente artigo relata uma pesquisa-ação realizada em uma atividade de campo, como pré-requisito exigido para o cumprimento das atividades planejadas para a disciplina de Fundamentos da Química II, um dos componentes curriculares do curso de licenciatura em Ciências da Natureza. A referida pesquisa, de cunho qualitativo, foi conduzida com 30 alunos $(n=30)$ do curso supracitado. Sobre a natureza de uma pesquisa qualitativa, Mayring (2002) apresenta seis delineamentos, sendo a pesquisa-ação um deles. A pesquisa-ação surgiu, no escopo deste trabalho, mediante a necessidade de superar a lacuna entre a teoria e a prática (ENGEL, 2000) que estes alunos enfrentaram ou enfrentam durante a sua formação inicial. Visando alcançar os objetivos desta pesquisa, a metodologia abordada dentro do universo da pesquisa-ação foi subdividida em etapas. Sendo estas:

\section{1) Aplicação das atividades para solução dos problemas apresentados durante a aula de campo}

Foi proposta uma série de atividades-problema aos alunos durante a aula de campo, envolvendo os conteúdos inseridos no ementário da disciplina. Segundo Krasilchik (2005), as aulas de campo, geralmente, são colocadas após a apresentação dos conteúdos curriculares em sala de aula. No caso desta pesquisa, a aula de campo ocorreu durante o processo de explanação dos conteúdos. Assim, para tornar a realização da atividade mais objetiva e organizada, foi elaborado um "guia" para a proposição das situações-problemas, adaptado do capítulo “A solução de problemas - aprender a resolver, resolver para aprender”, dos autores Pérez Echeverría e Pozo (1998), presente no livro A Solução de Problemas, conforme pode ser visto no Quadro 1. 
Quadro 1: Fases de um problema e sugestões para o seu desenvolvimento. Fonte: Adaptado de Pérez Echeverría e Pozo (1998).

\begin{tabular}{|c|c|c|}
\hline \multicolumn{3}{|c|}{$\begin{array}{c}\text { EXPOSIÇÃO DO MARCO TEÓRICO } \\
\text { - Ponto de referência e orientação constante da atividade; } \\
\text { - Dar auxílio quando o desenvolvimento da atividade assim o exigir. }\end{array}$} \\
\hline $\begin{array}{c}\text { REPRESENTAÇÃO E DEFINIÇÃO } \\
\text { DO PROBLEMA }\end{array}$ & $\begin{array}{c}\text { ELABORAÇÃO E SOLUÇÃO DO } \\
\text { PROBLEMA }\end{array}$ & $\begin{array}{c}\text { REFLEXÃO E AVALIAÇÃO DOS } \\
\text { RESULTADOS }\end{array}$ \\
\hline $\begin{array}{l}\quad \text { Tornar o problema } \\
\text { significativo; } \\
\text { - Criar certa expectativa nos } \\
\text { alunos; } \\
\text { - Fazer com que os alunos façam } \\
\text { previsões para que aflorem os } \\
\text { seus conhecimentos prévios. }\end{array}$ & $\begin{array}{l}\text { - Formular as perguntas para } \\
\text { concentrar-se nas capacidades } \\
\text { essenciais dos alunos; } \\
\text { - Garantir informações } \\
\text { suficientes aos alunos; } \\
\text { - Favorecer a interação entre os } \\
\text { alunos. }\end{array}$ & $\begin{array}{l}\text { - Dar mais atenção ao processo } \\
\text { do que aos resultados; } \\
\text { - Tornar os alunos conscientes } \\
\text { de suas ideias preconcebidas, } \\
\text { tanto em relação aos conceitos } \\
\text { como aos procedimentos; } \\
\text { - Melhorar e enriquecer o } \\
\text { modelo teórico. }\end{array}$ \\
\hline \multicolumn{3}{|c|}{ ATIVIDADES PLANEJADAS E DESENVOLVIDAS DURANTE A AULA DE CAMPO EM PARNAÍBA - PI } \\
\hline $\begin{array}{l}\text { - Foi dado um "guia" para os } \\
\text { alunos, informando as etapas } \\
\text { que fariam parte da proposta, } \\
\text { tais como a manipulação de } \\
\text { objetos, questões, observação, } \\
\text { etc.; } \\
\text { - Foram coletadas amostras de } \\
\text { água de diferentes pontos do } \\
\text { Delta do Parnaíba, para } \\
\text { posterior análise }{ }^{2} \text {; } \\
\text { - Foram formulados problemas } \\
\text { envolvendo os conteúdos } \\
\text { ministrados na disciplina de } \\
\text { Fundamentos da Química Il. }\end{array}$ & $\begin{array}{l}\text { - As atividades foram realizadas } \\
\text { por } 6 \text { (seis) equipes, contendo } 5 \\
\text { (cinco) componentes cada; } \\
\text { - Foi implantado o espírito de } \\
\text { desafio entre as equipes e de } \\
\text { colaboração entre os seus } \\
\text { membros; } \\
\text { - No final de cada dia, as } \\
\text { equipes, representadas por um } \\
\text { líder, respondiam a um } \\
\text { conjunto de questões sobre as } \\
\text { atividades desenvolvidas. A } \\
\text { cada líder era permitido } \\
\text { dialogar com sua referida } \\
\text { equipe antes de atribuir as } \\
\text { respostas aos problemas; } \\
\text { - Por fim, era realizada uma } \\
\text { roda de conversa acerca dos } \\
\text { resultados apresentados por } \\
\text { cada equipe, de modo que cada } \\
\text { uma delas opinava sobre os } \\
\text { dados obtidos ou sobre as } \\
\text { respostas dadas pelas outras } \\
\text { equipes. }\end{array}$ & $\begin{array}{l}\text { - Cada aluno, individualmente, } \\
\text { respondeu a um questionário } \\
\text { com auxílio de um tablet, } \\
\text { usando o aplicativo Formz } \\
\text { como recurso para a } \\
\text { construção do questionário. }\end{array}$ \\
\hline
\end{tabular}

\footnotetext{
${ }^{2}$ Foi utilizado um kit portátil para análise da qualidade das amostras de água coletadas em diferentes pontos do Delta do Parnaíba - Pl. Com o kit, da marca Allied Signal, foi possível realizar testes sobre as quantidades de amônio, fosfato, nitrato, nitrito, além de verificar o grau de dureza e pH das amostras.
} 


\section{2) Coleta de dados e tratamento}

Foram feitas observações diretas pela professora participante e propositora da referida pesquisa, as quais foram registradas em um diário de campo, o qual representa um instrumento que "consiste num conjunto de narrações que refletem as perspectivas do professor, nas dimensões objetiva e subjetiva, sobre os processos mais significativos da sua ação" (SILVA e DUARTE, 2002, p. 74). Os comentários sobre as observações extraídas, a partir da atividade, serão inseridos ao longo das discussões sobre os resultados.

Para coletar os dados dos alunos, foi aplicado um questionário ao final das atividades. O instrumento para coleta de dados utilizados foi do tipo Escala de Likert. Segundo Araújo e Laburú (2009), a Escala Likert estabelece uma escala numérica, na qual a resposta favorável recebe o valor mais alto e a mais desfavorável recebe o valor mais baixo, caracterizando a escala ordinal ou por pontos. Os alunos responderam ao questionário individualmente, o qual continha questões que foram previamente elaboradas. Para a coleta das respostas atribuídas à pesquisa, foi utilizado o aplicativo Form $z^{\circledR}$, com o auxílio de um tablet. No questionário foram disponibilizados cinco itens de Likert, com ponto neutro, contendo opções de resposta que variavam de concordo totalmente, concordo e indeciso a discordo e discordo totalmente.

Os dados obtidos nesta pesquisa foram tratados a partir do enfoque qualitativo, embora tenha sido necessário recorrer a um tratamento quantitativo, visando tornar as respostas dos alunos mais objetivas. Pois, de acordo com Neves (1996), ao combinar técnicas qualitativas com quantitativas, torna-se a pesquisa mais consistente.

\section{Resultados e discussões}

Almejando perspectivas de favorecer o ensino por investigação e a sua aplicação em espaços não formais de educação, buscou-se então, neste trabalho, a execução de uma proposta didático-pedagógica, tendo como aporte as visões sociointeracionistas de Vygotsky. E, para tanto, foram investigadas algumas concepções dos futuros professores de Ciências da Natureza acerca da atividade proposta e sua relação com a construção identitária sobre os saberes docentes. 
Isto posto, o instrumento utilizado para a coleta de opiniões dos estudantes de licenciatura em Ciências da Natureza continha dez (10) questões assertivas. Este visava averiguar a discordância de opiniões entre as questões. Assim, estas foram agrupadas intencionalmente, com o intuito de traçar um perfil sobre as concepções dos licenciados. O número total de respondentes foi de trinta professores em formação inicial $(n=30)$. Os gráficos abaixo revelam os resultados obtidos.

Gráfico 1: Assertiva 1 e 2 - (1) As aulas de campo são importantes, pois favorecem a aproximação entre a teoria e a prática. (2) Os métodos utilizados perante o ensino de ciências precisam estar em constantes mudanças.

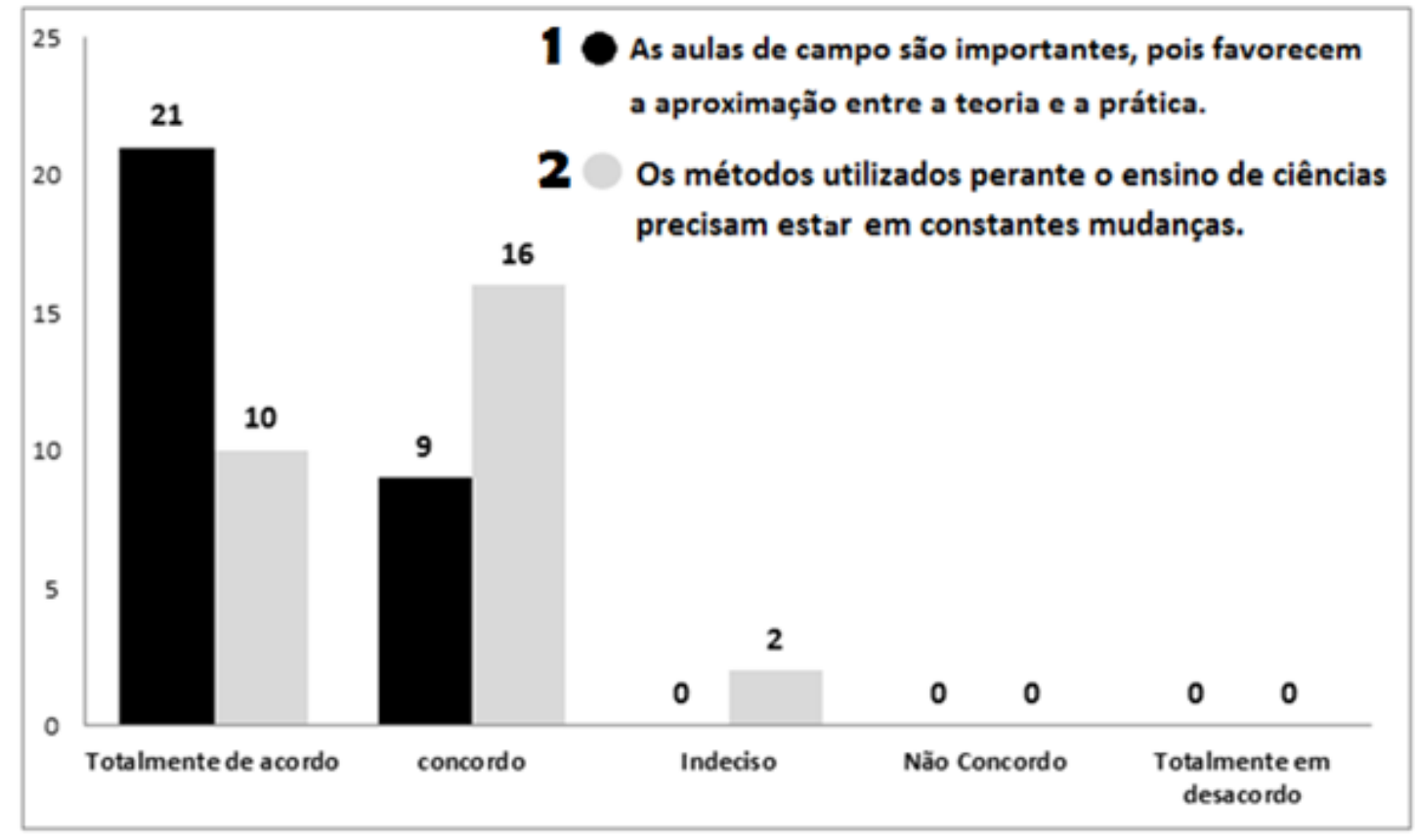

Conforme pode ser observado no Gráfico 1, para os respondentes, a opinião sobre a assertiva 1 indica que 72,41\% (21) dos licenciandos estão totalmente de acordo com esta afirmação, enquanto 31,03\% (9) apenas concordam. É importante notar que um aluno não respondeu às assertivas. Percebe-se que a maioria dos alunos é a favor das aulas de campo como forma de integrar teoria e prática, diminuindo, assim, esta dicotomia. Trojan (2008) defende que o processo de ensino e aprendizagem envolve conhecimentos teóricos e práticos, e, sendo uma atividade intencional, exige do professor conhecimentos, proposição de objetivos, planejamento, intervenção e avaliação para 
atingir sua finalidade, que é a formação humana em determinado contexto social. Deste modo, as atividades realizadas em espaços não formais de educação, tal como uma aula de campo, favorecem aos alunos um cenário potencialmente rico em situações didáticopedagógicas que possam levá-los à aproximação entre a teoria e a prática. Contudo, é crucialmente importante que o professor mentor da atividade planeje todas as etapas de execução e crie contextos para que os alunos possam colocar em execução alguns conhecimentos que aprenderam em um espaço formal de educação. Marandino et al. (2009) asseguram que, nos espaços não formais, o aluno tem a possibilidade de atribuir significado ao que percebe, pois pode utilizar uma série de estratégias interpretativas, abarcando aspectos pessoais, cognitivos, afetivos, sociais e políticos.

A assertiva 2, representada pelo Gráfico 1, demonstra que 34,48\% (10) dos alunos estão totalmente de acordo com a assertiva "os métodos utilizados perante o ensino de ciências precisam estar em constantes mudanças". Já 55,17\% (16) destes apenas concordam, ao passo que cerca de 6,89\% (2) dos alunos não opinaram, ou seja, estavam indecisos. Estes dados sugerem que as visões destes futuros professores de Ciências se enquadram em um perfil que tende a seguir uma linha tradicional como método de ensino, mas com possibilidades de incorporarem novas estratégias metodológicas em suas aulas, de modo que eles (futuros professores) não sejam os únicos responsáveis pelo processo de ensino e aprendizagem das Ciências, permitindo que os seus alunos possam participar do seu próprio processo de construção do conhecimento, sendo mais dinâmicos, interativos e colaborativos, realizando, assim, um ciclo contínuo entre aprender e ensinar.

De acordo com Cachapuz et al. (2011), para uma ressignificação do ensino das Ciências, é necessário que haja, por parte dos professores, uma renovação na teoria da ciência, acompanhada por uma renovação didático-metodológica de suas aulas. Neste sentido, as posições pedagógicas face aos problemas na sala de aula e na escola não são independentes da mentalidade, da cultura geral e das atitudes dos professores (NUÑEZ et al., 2009). Desta forma, infere-se que a grande maioria desses professores em formação inicial está mais favorável a repetições metodológicas do que, necessariamente, a inserir novas estratégias de ensino que possam enriquecer a sua 
práxis docente. Tal afirmação pode ser comprovada constantemente durante o desenvolvimento do estágio supervisionado.

Durante a execução das atividades, foi observada uma predisposição dos alunos a vivenciarem uma situação didática diferenciada. Este fato era esperado, tendo em vista que uma atividade em espaço não formal pode promover a motivação, habilidades e atitudes, modos de raciocinar, argumentação, expectativa sobre as experiências que serão adquiridas, entre outros benefícios.

Gráfico 2: Assertiva 3 e 4 - (3) Ensinar Ciências é fácil. Basta usar o livro didático. (4) Eu prefiro sempre as aulas tradicionais.

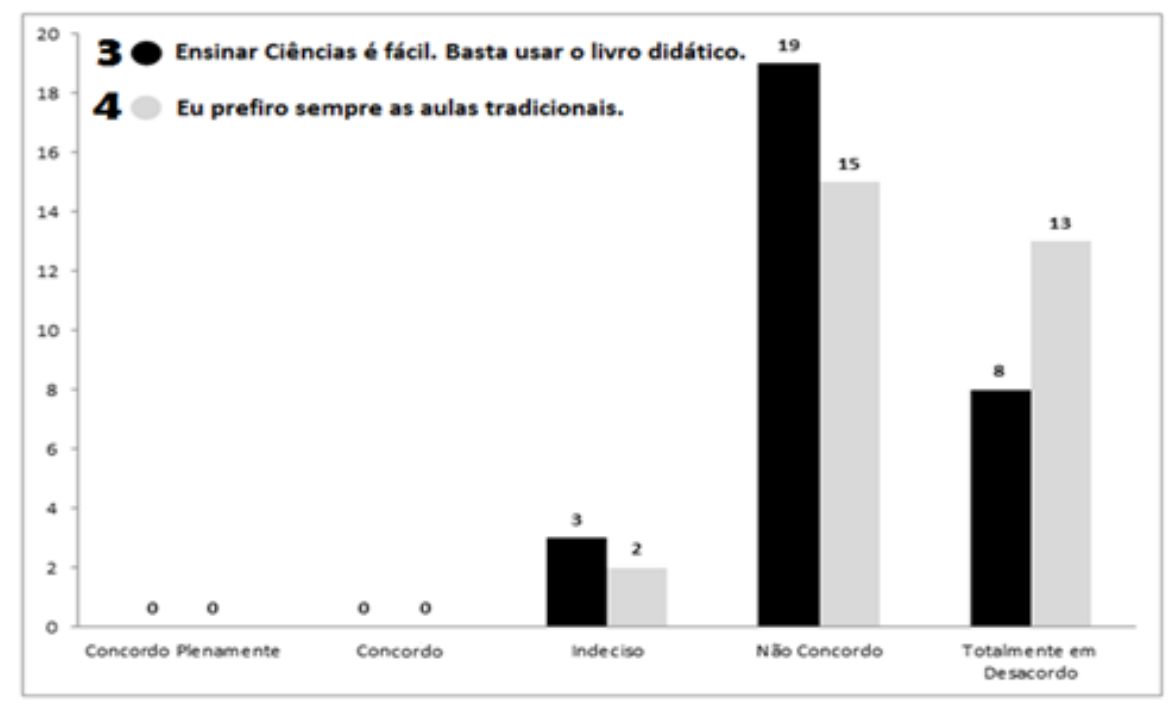

O Gráfico 2 mostra os dados obtidos a partir das respostas atribuídas às assertivas 3 e 4. Das opiniões emitidas pelos alunos, é possível depreender que a maioria deles não concorda com a assertiva 3, de que "é fácil ensinar Ciências, bastando apenas o livro didático", representando 63,34\% (19). Em contraponto, aqueles que estão totalmente em desacordo representaram cerca de $26,67 \%$ (8) dos respondentes. Um total de $10 \%$ (3) não opinou ou ficou indeciso. Este resultado é preocupante, pois o percentual referente ao totalmente em desacordo $(43,33 \%$ - 13) deveria ter sido maior do que o não concordo (50\% - 15), pois este resultado fornece indícios de uma possível dependência dos discentes em relação ao uso exclusivo do livro didático para ensinar ciências, ou seja, isto denota uma concepção simplista e limitatória sobre os inúmeros recursos que podem ser utilizados durante o processo de ensino e aprendizagem. Tal pressuposição pode ser 
fortalecida com o que defendem Verceze e Silvino (2008, p. 99), os quais alegam que o livro didático "deve ser visto apenas como um dos instrumentos de apoio necessário ao trabalho pedagógico”. Ainda nesta perspectiva, é sabido que os livros didáticos podem ser, e são, na maioria das vezes utilizados como instrumentos educacionais que auxiliam os educadores a organizarem suas ideias, assimilar os conteúdos e proceder à exposição aos alunos, porém, o professor deve evitar utilizar apenas este recurso didático em suas aulas (LOBATO, 2007). Por fim, os resultados extraídos do Gráfico 2, por meio da assertiva 3, nos levam a acreditar que esses discentes demonstram uma visão ingênua ou deturpada sobre o verdadeiro papel do livro didático, o qual deve servir como guia pedagógico, e nunca deve ser considerado o único norteador e instrumento de todas as suas ações exercidas ao longo do processo de ensino e aprendizagem dos seus alunos.

Quanto à assertiva 4, representada no Gráfico 2, mostra-se que 50\% (15) dos alunos não concordam com a afirmação "eu prefiro sempre aulas tradicionais". Já 43,34\% (13) estão totalmente em desacordo e 6,67\% (2) dos alunos se demonstraram indecisos diante desta assertiva. Pode-se perceber o quanto é paradoxal para estes professores tal questão que versa sobre suas concepções em relação ao ensino meramente tradicionalista. Sobre este tradicionalismo no ensino, Pozo e Crespo (2009) esclarecem que:

[...] novas demandas não podem ser satisfeitas com um modelo educacional meramente transmissivo, unidirecional, em que o professor atua unicamente como provedor de um saber cultural acabado e no qual os alunos se limitam a ser apenas receptores mais ou menos passivos. (POZO e CRESPO, 2009, p. 251)

Desse modo, esses futuros professores demonstram, não de forma tão convincente, que estão "conscientes" da necessidade de inovar suas ações docentes, alternando-as entre ensino tradicional e as novas vertentes educacionais que possam ser aplicadas em sua vida profissional. A ideia maior é discutir, incansavelmente, durante o processo de formação destes professores, sobre a importância de se produzir conhecimento e não apenas transmiti-lo, mantendo sempre uma atitude reflexiva sobre o seu papel como professor diante do ciclo dialético entre aprender e ensinar. 
No que tange à importância sobre a reflexão da ação docente, Schön (2003, p. 119) explica que "trata-se de olhar retrospectivamente para a ação e refletir sobre o momento da reflexão na ação, isto é, sobre o que aconteceu, o que o profissional observou, que significado atribui e que outros significados pode atribuir ao que aconteceu". Galiazzi (2000) assegura que a reflexão sobre as próprias concepções do docente poderá se constituir em um agente transformador das licenciaturas. Neste segmento, a reflexão deve ser entendida e vista "como um processo em que o professor analisa sua prática, compila dados, descreve situações, elabora teorias, implementa e avalia projetos e partilha suas ideias com colegas e alunos, estimulando discussões em grupo" (PERÉZ, 2004, p. 252).

Gráfico 3: Assertiva 5 e 6 - (5) Aplicar os conhecimentos sobre a Química em uma situação real ajuda a desmistificar a Ciência. (6) Entender a Química a partir da investigação é essencial.

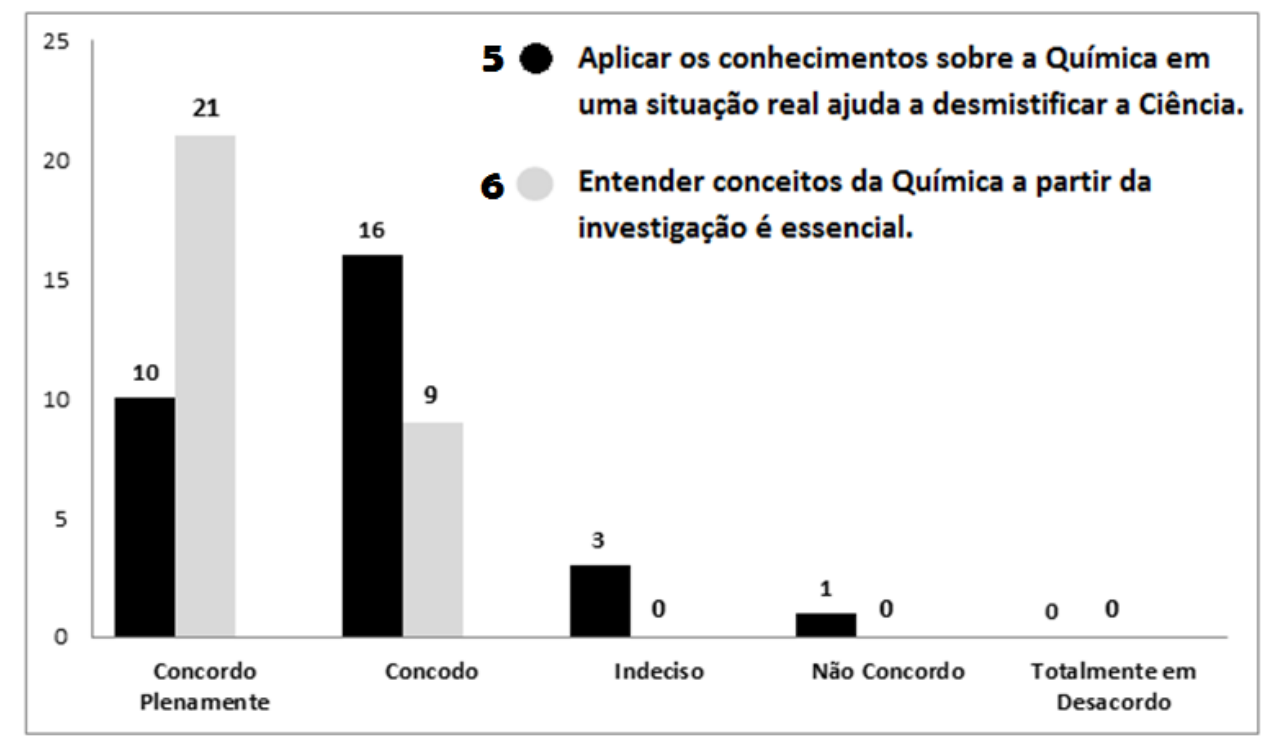

Quanto à assertiva 5, "aplicar os conhecimentos de Química em uma situação real ajuda a desmistificar a Ciência" (exibida pelo Gráfico 3), observa-se que os resultados foram variados, havendo concordância plena em somente 33,34\% (10) das opiniões dos respondentes, sendo que 53,34\% (16) apenas concordaram com a assertiva, 10\% (3) ficaram "neutros" ou indiferentes e 3,34\% (1) não concordaram. Desmitificar a ciência, neste contexto, se designa a favorecer a aproximação do aluno com o conhecimento 
científico, ao vivenciar possibilidades de aplicação, na prática, dos seus conhecimentos adquiridos na disciplina de Fundamentos II. Para Bachelard (1977), a apropriação do conhecimento científico pelo aluno implica na superação de "obstáculos epistemológicos". Para ele, é pelas rupturas que o conhecimento científico se constrói; de forma semelhante, é pelas rupturas que se passará do conhecimento vulgar para o conhecimento científico (BACHELARD, 1977). Logo, os professores precisam aprender a transformar os conhecimentos empíricos dos seus alunos em algo mais efetivo, ou seja, em um conhecimento mais científico. É importante ressaltar que "cabe aos professores saber selecionar conteúdos adequados que apresentem uma visão correta da Ciência e que sejam acessíveis e interessantes aos alunos" (MENEZES, 1996, p. 152). Desta forma, a aprendizagem de conceitos pode colaborar para a sistematização e conscientização do conhecimento adquirido espontaneamente na vivência cotidiana (VYGOTSKY, 2007).

No tocante às respostas atribuídas à assertiva 6, "entender a Química a partir da investigação é essencial”, revelou-se uma significativa aceitação dos alunos, pois 70\% (21) destes concordaram plenamente, enquanto que 30\% (9) apenas concordaram. Provavelmente, o resultado de $70 \%$ nos fornece indícios da boa aceitabilidade, pelos alunos, das atividades realizadas ao longo de três dias durante a aula de campo. Segundo Garrido et al. (1995),

É preciso que sejam realizadas diferentes atividades, que devem estar acompanhadas de situações problematizadoras, questionadoras e de diálogo, envolvendo a resolução de problemas e levando à introdução de conceitos para que os alunos possam construir seus conhecimentos. (GARRIDO et al., 1995, p. 20)

Promover um ensino por investigação é, sobretudo, garantir aos alunos que estes estejam envoltos em um processo de reflexão, arraigado na sua possibilidade de observar, executar, formular hipóteses, interagir, avaliar, etc., e que, sobretudo, perpassem diferentes caminhos e alternativas para resolver um determinado problema. No entanto, esta não é uma tarefa fácil, pois, “com uma visão de ciência como algo absolutamente verdadeiro e acabado, os alunos terão dificuldade em aceitar a possi- 
bilidade de haver mais de uma alternativa para resolver um determinado problema" (SANTOS e MORTIMER, 2000, p. 138).

Gráfico 4: Assertiva 7 e 8 - (7) O professor de Ciências deve sempre reformular sua didática para ensinar Ciências. (8) Ser professor é estar sempre em formação.

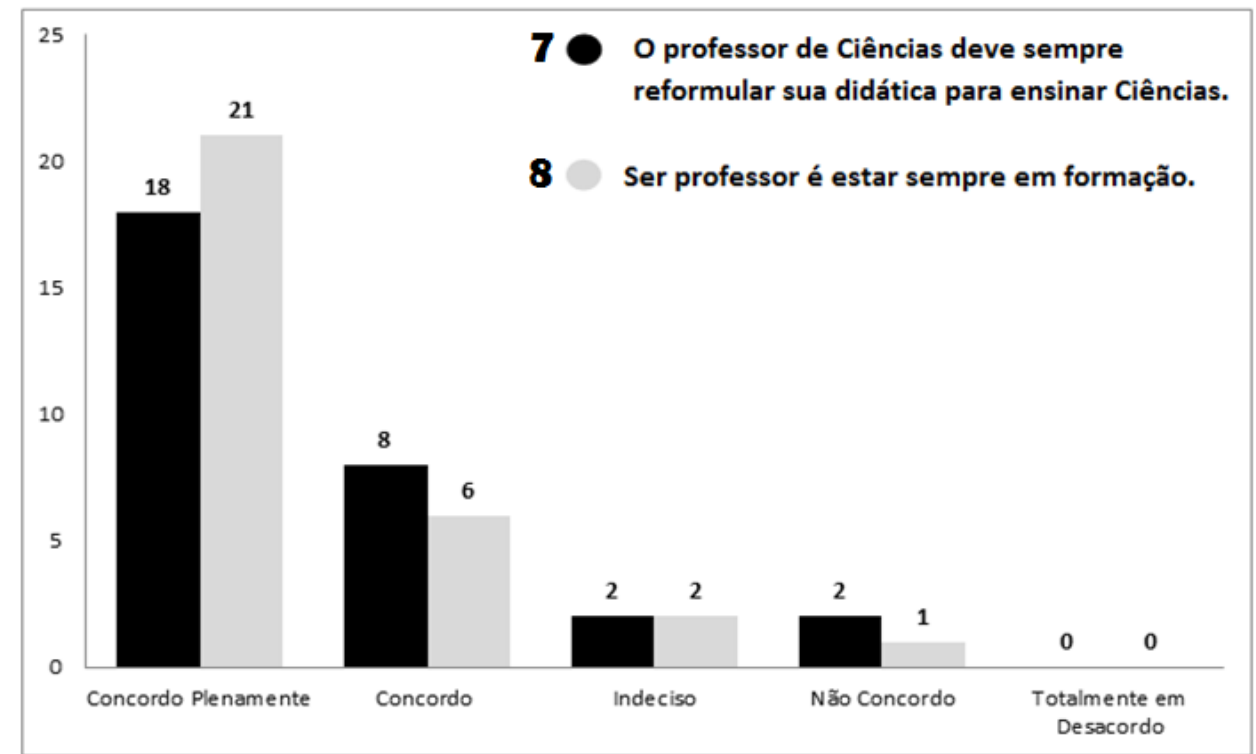

Conforme observado no Gráfico 4, a opinião dos alunos sobre a assertiva 7 exibe que 60\% (18) dos licenciandos concordaram plenamente com essa afirmação, enquanto 26,67\% (8) apenas concordaram. Já o percentual de indiferentes e dos que não concordam com tal assertiva apresentou valores iguais, ou seja, 6,67\% (2). Fica evidenciado que a maioria dos alunos tem consciência da necessidade da reflexão constante sobre suas ações como docentes. Maurice Tardif, em seu livro Saberes docentes e formação profissional, menciona que:

Os professores não buscam somente realizar objetivos; eles atuam, também, sobre um objeto. Este objeto são seres humanos individualizados e socializados ao mesmo tempo [...] Assim, os alunos são ativos e capazes de oferecer resistência às iniciativas do professor. (TARDIF, 2012, p. 130) 
É evidente que as relações de cunho afetivo entre professor e alunos não podem ser excluídas desse processo. Contudo, cabe ao professor mediar ou contornar situações de rejeição dos alunos sobre sua metodologia de ensino, readaptando-a, inovando-a ou até mesmo implantando um diálogo aberto com os seus alunos sobre sua metodologia. Isso o faria refletir, pois o futuro professor precisa estar consciente sobre as modificações ou reformulações diante de suas estratégias didático-pedagógicas para ensinar ciências; no entanto, é preciso que o professor esteja flexível a estas situações.

Em relação à assertiva 8, conforme pode ser visto no Gráfico 4, apresentou-se um resultado positivo, pois $70 \%$ (21) dos licenciandos concordaram plenamente com a afirmação "Ser professor é estar sempre em formação", já 20\% (6) apenas concordam, 6,67\% (2) mostraram-se neutros ou indiferentes diante desta assertiva e 3,34\% (universo amostral de $n=1$ aluno) não concordam com esta assertiva. Estes dados são representativos e corroboram uma possível mudança de concepções acerca do papel docente. Como futuros professores, eles estão coesos sobre a necessidade de "renovarse" com frequência em sua atuação profissional, pois não é mais cabível que um professor seja apático ao processo de renovação da sua prática pedagógica. $O$ aluno que não concordou com tal necessidade, provavelmente, não abraçou a docência com afinco, ou talvez desconheça todos os significados implícitos e explícitos para uma boa atuação docente.

A formação de um professor é um processo a longo prazo que não se finaliza com a obtenção do título de licenciado, mesmo que a formação recebida tenha sido da melhor qualidade; isso ocorre porque a formação docente é um processo complexo para o qual são necessários muitos conhecimentos e habilidades, que não são todos adquiridos no curto espaço de tempo que dura a formação inicial. (MENEZES, 1996, p. 3)

Seguindo essa vertente, Schön (2003) sinaliza que a formação docente deve ser capaz de fazer o professor refletir criticamente sobre suas ações. Ele considera que os aspectos teóricos são insuficientes para nortear a prática docente, porque o professor não deve ser o especialista que apenas aplica o conhecimento, mas um prático reflexivo, ou seja, um profissional que age e toma decisões, avaliando os problemas que surgem no decorrer de sua práxis docente. Decerto, Vygotsky complementa que a colaboração e 
orientação a partir de "demonstração, questões norteadoras e introdução dos elementos iniciais de solução da tarefa" (VYGOTSKY, 1988, p. 89) são importantes para permitir a construção de conhecimentos.

Gráfico 5: Assertiva 9 e 10 - (9) Aulas em espaços não formais são bastante ricas para favorecer a contextualização e interação entre os sujeitos. (10) O meio ambiente é excelente local para aprender e ensinar Ciências.

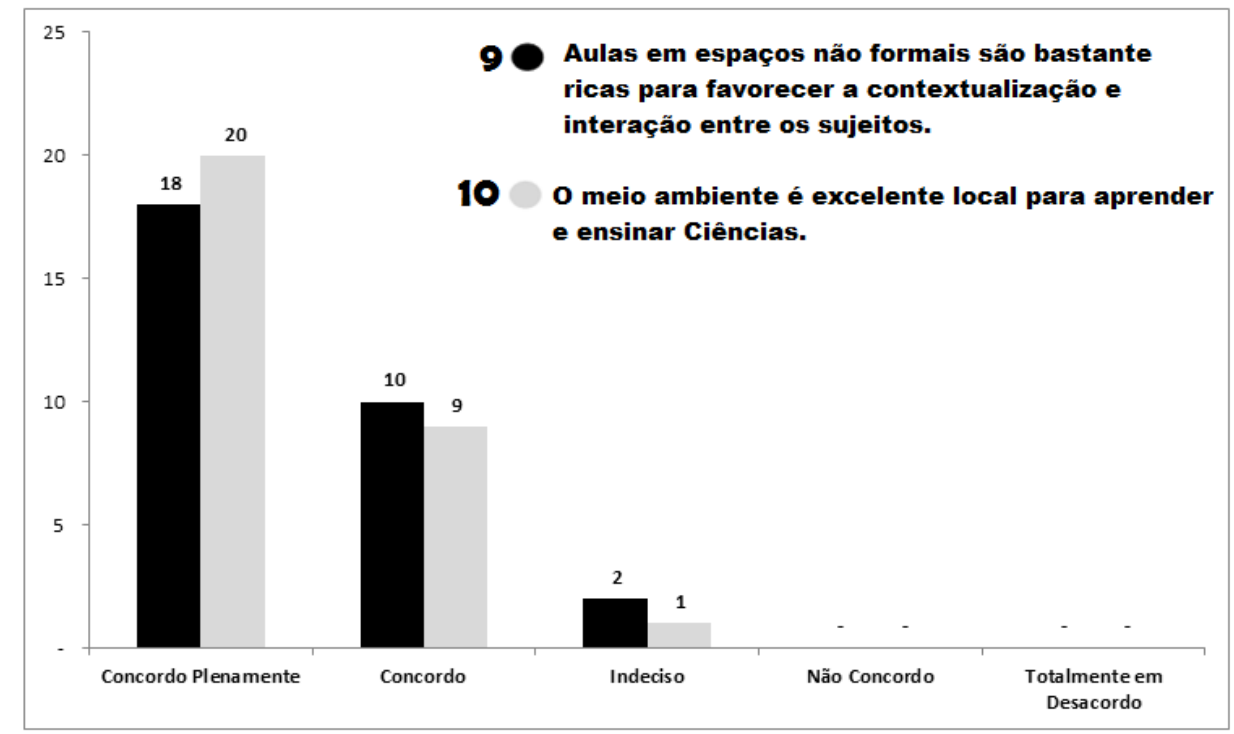

O Gráfico 5 mostra que a afirmação 9 teve aceitação de 60\% (18) dos alunos, pois estes concordaram plenamente com a mesma. Notadamente, 33,34\% (10) apenas concordaram. Já 6,67\% (2) mostraram-se indecisos em relação à assertiva 9. As aulas em espaços não formais, quando bem planejadas, são basilares fundamentais para o enriquecimento da aprendizagem de diferentes conteúdos, pois se tornam motivadoras e desafiadoras. A contextualização é, certamente, intrínseca aos momentos em que ocorrem as aulas em espaços não formais, sendo ela indissociável da atividade, pois não há como evitá-la diante das inúmeras possibilidades que estes espaços promovem. Gohn (2006), ao discutir sobre contextos que envolvem movimentos sociais, ressalta que na educação formal quem educa é o professor, enquanto, na educação não formal, o grande educador é o outro, aquele com quem interagimos ou nos integramos. No sentido de complementaridade, pode-se dizer que a educação em espaço não formal abre 
possibilidades de conhecimento sobre o mundo que rodeia os indivíduos e suas relações sociais (CLEOPHAS et al., 2011).

A educação que acontece nos espaços não formais compartilha muitos saberes com a "escola", muitos dos quais são construídos a partir das teorias elaboradas pelas ciências da educação (ROCHA e FACHÍN-TERÁN, 2010). Ainda na concepção de FachínTerán (2013), a educação científica tende a ganhar muito, quando executadas em espaços não formais, pois promove uma flexibilidade em relação ao tempo, aos objetivos e conteúdos necessários para a aprendizagem. Acredita-se ainda que a proposição de situações que contribuam com a construção do processo de ensino e aprendizagem em espaços não formais tende a colaborar para a mobilização de diferentes habilidades cognitivas, além de auxiliar o surgimento da interação social entre os envolvidos.

Durante a execução da atividade, percebeu-se que a relação entre os discentes foi pautada na colaboração, pois o aluno que apresentava uma maior experiência ou detinha um maior conhecimento sobre os conteúdos necessários para a resolução dos problemas originados pelas situações-problemas impostas auxiliava os demais na busca pela resolução dos problemas propostos. Portanto, Zanella (1994) sustenta que, para Vygotsky, existe a concepção de que o indivíduo menos experiente, inevitavelmente, aprende, a partir da interação com um parceiro mais experiente. Assim, notam-se indícios de ocorrência da ZDP, porque foram observados aspectos interacionistas, o que, conforme Calil (1991), consiste em um campo de situações construído na interação social.

Finalmente, os resultados obtidos para a assertiva 10, conforme mostrado no Gráfico 5, exibem um panorama sobre a importância do meio ambiente para aprender e ensinar ciências. Entre os licenciandos, 66,67\% (20) concordaram totalmente com esta afirmação, ao passo que 30\% (9) apenas concordaram e 3,37\% (1) permaneceram indecisos. É inegável afirmar que o meio ambiente é promissor como interlocutor entre a teoria e a prática, pois permite inúmeras articulações entre o conteúdo teórico e o cotidiano. Neste contexto, ele se configura como um espaço que permite a contextualização, a interação, a construção de novos conhecimentos, a mediação entre os sujeitos, a interdisciplinaridade, entre outros benefícios. É importante que os futuros professores de Ciências possam propiciar aos seus alunos o ensino por investigação, propondo, assim, aulas em espaços não formais (utilizando o meio ambiente), mostrando 
para seus alunos a importância da reflexão e da criticidade, e que, sobretudo, os conteúdos ministrados em sala de aula não estão isolados do ecossistema. A proposta didático-pedagógica realizada no Delta do Parnaíba (PI) certamente contribuiu para que os futuros professores compreendessem a importância do professor em sistematizar os conhecimentos que foram gerados por seus alunos durante o processo de ensino e aprendizagem, não no sentido de fornecer respostas finais, mas, sim, de assumir um papel de crítico, questionando-os (CARVALHO et al., 1998).

De um modo geral, conseguiu-se que os alunos pudessem alcançar "um pensar crítico e reflexivo acerca dos problemas sociais que envolvem o seu meio, buscando transformá-lo".

\section{Considerações finais}

No que diz respeito às relações sociointeracionistas, propostas por Vygotsky, a realização da proposta didático-pedagógica favoreceu um forte estreitamento entre os integrantes das equipes, ficando evidenciadas a interação e a construção argumentativa entre eles, com vistas à resolução dos problemas que foram colocados à disposição dos alunos perante a atividade proposta.

Percebeu-se que os futuros professores se sentiram motivados a utilizar o meio ambiente como cenário para o fortalecimento do seu aprendizado, colocando em prática elementos que o ensino por investigação proporcionou, tais como o levantamento de hipóteses, manifestação de habilidades cognitivas para a resolução das diferentes situações-problemas que emergiram durante a execução da proposta, argumentação, interação, etc.

Devido às diferentes situações-problemas impostas ao longo dos três dias de aula de campo, os alunos tiveram a oportunidade de mobilizar diferentes saberes, objetivando, assim, resolver os problemas sugeridos. O espírito de colaboração entre os alunos de uma mesma equipe foi acentuado, evidenciando, dessa maneira, aspectos sociointeracionistas, pois se percebeu que a aprendizagem colaborativa emergiu naturalmente durante a resolução dos problemas. 
Em relação ao questionário aplicado, notou-se que os professores em formação inicial, investigados nesta pesquisa, estão construindo a sua identidade docente, e a participação em atividades, tal como a proposta por este trabalho, favoreceu múltiplos meios para compreender a importância da contextualização e da interdisciplinaridade no Ensino de Ciências. E que a experiência proporcionada pelo ensino por investigação em espaços não formais contribuiu para o processo de ensino e aprendizagem, além de possibilitar enxergar que a construção de diferentes situações didático-pedagógicas é importante para transformar, futuramente, o saber cotidiano dos seus alunos em um saber científico.

Por fim, com este trabalho é possível inferir que a grande maioria dos alunos, sujeitos desta pesquisa, vem delineando a construção de sua identidade docente. Os discentes demonstraram que estão conscientes da necessidade de incorporar, em sua futura práxis docente, um processo contínuo de modo a favorecer a inserção de outros métodos de ensino (que se diferenciem do ensino tradicional) e de estratégias didáticas diversificadas em seu campo de atuação profissional, contornando, assim, algumas dificuldades encontradas em sala de aula e, desta forma, contribuindo para um melhor aprendizado dos seus alunos. Por fim, acredita-se que estes futuros professores tenderão a mobilizar diferentes recursos para transformar o saber cotidiano dos seus alunos em um saber mais científico, por meio do planejamento e da inclusão de diferentes atividades didático-metodológicas no ensino das Ciências. 


\section{Referências}

ARAÚJO, Nelci Reis Sales de; LABURÚ, Carlos Eduardo. Uma análise da validação e confiabilidade da escala de opiniões da seleção de experimentos de Química (EOSEQ). Revista Ensaio Pesquisa em Educação em Ciências, v. 11, n. 2, p.01-22, 2009.

AZEVEDO, Maria Nizete de; ABIB, Maria Lúcia. Pesquisa-ação e a elaboração de saberes docentes em ciências. Investigações em Ensino de Ciência, v. 18, n. 1, p. 55-75, 2013.

BACHELARD, Gaston. O racionalismo aplicado. Rio de Janeiro, RJ: Jorge Zahar, 1977.

BACHELARD, Gaston. A formação do espírito científico: contribuição para uma psicanálise do conhecimento. Rio de Janeiro, RJ: Contraponto, 1996.

BORGES, Tarciso. Novos rumos para o laboratório escolar de ciências. Caderno Brasileiro de Ensino de Física, v. 19, n. 3, p. 291-313, 2002.

BRASIL, Ministério da Educação e Cultura. Parâmetros curriculares nacionais para o ensino médio. Brasília, DF: MEC/Semtec, 2006.

BRUNER, Jerome. Vygotsky: An historical and conceptual perspective. In: Culture, communication, and cognition: Vygotskian perspectives. London: Cambridge University Press., 1985. p. 368.

CACHAPUZ, António. et al. A necessária renovação do ensino das ciências. $3^{a}$. ed. São Paulo, SP: Cortez, 2011.

CALIL, Eduardo. A construção de zonas de desenvolvimento proximal em um contexto pedagógico. [134 f.] Dissertação de Mestrado à Univerisidade de São Paulo: Faculdade de Educação, 1991.

CARVALHO, Ana Maria Pessoa de. Las practices experimentales en el proceso de enculturación cientifica. In: GATICA, Mario Quintanilla; ADÚRIZ-BRAVO, Agustín. (Eds.). Enseñar ciencias en el nuevo milenio: retos e propuestas. Santiago: Universidade católica de Chile, 2006.

CARVALHO, Anna Maria Pesoa de. et al. Ensino de ciências por investigação: condições para implementação em sala de aula. 1 $^{\text {}}$. ed. São Paulo, SP: Cengage Learning, 2013.

CARVALHO, A. M. P.; VANNUCCHI, Andrea Infantosi; BARROS, Marcelo Alves; GONÇALVES, Maria Elisa Resende; REY, Renato Casal de. Ciências no Ensino Fundamental: o conhecimento físico. São Paulo: Scipione, 1998.

CARVALHO, Anna Maria Pessoa de. Habilidades de professores para promover a enculturação Científica. Revista Contexto \& Educação, v. 22, n. 77, p. 25-49, 2007. 
CHARAUDEAU, Patrick. Para uma nova análise do discurso. In: CARNEIRO, Alan Dionizio. (Ed.). O discurso da mídia. Rio de Janeiro, RJ: Oficina do Autor, 1996.

CLEMENT, Luiz; CUSTÓDIO, José Francisco; ALVEZ FILHO, José de Pinho. Potencialidades do ensino por investigação para Promoção da motivação autônoma na educação científica. Alexandria - Revista de Educação em Ciência eTecnologia, v.8, n.1, p.101-129, 2015.

CLEOPHAS, Maria das Graças Porto. et al. O Ensino de química e física em espaços nãoformais. In: VIII ENPEC - ENCONTRO NACIONAL DE PESQUISA EM EDUCAÇÃO EM CIÊNCIAS, Universidade Estadual de Campinas, 05 a 09 de dezembro. Anais... Campinas, SP: ABRAPEC, 2011.

COUTO, Maria Elizabete Souza. Aprender a ser professor: docência e formação continuada na modalidade a distância. Debates em Educação, v. 1, n. 1, p. 1-15, 2009.

DEMO, Pedro. Educar pela Pesquisa. $9^{\text {a }}$. ed. São Paulo, SP: Editora Autores Associados, 2007.

ECHEVERRÍA, Agustina Rosa; SOARES, Marlón Herbert Flora Barbosa. Um núcleo de pesquisa em Ensino de Ciências (NUPEC) e a mudança nos parâmetros da formação inicial e continuada de professores. In: ZANON, Lenir Basso.; MALDANER, Otavio Aloisio. (Eds.) . Fundamentos e propostas de ensino de química para a educação básica no Brasil. Unijuí RS: Unijuí, 2009. p. 171-189.

ENGEL, Guido Irineu. Pesquisa-ação. Educar, n. 16, p. 181-191, 2000.

FACHÍN-TERÁN, A. Fundamentos da Educação em Ciências. In: FACHÍN-TERÁN, Augusto; SANTOS, Saulo Cézar Seiffert (Orgs.). Novas perspectivas de Ensino de Ciênciasem espaços não formais amazônicos. Manaus: UEA edições, 2013.

FERNANDES, José Artur Barroso. Você vê essa adaptação? A aula de campo em ciências entre o retórico e o empírico. [326f.] Tese de Douturado em Educação apresentada à Univerisidade de São Paulo: Faculdade de Educação, 2007.

FOUREZ, Gérard. Crise no ensino de Ciências. Investigações em ensino de ciências, v. 8, n. 2, p. 109-123, 2003.

GALIAZZI, Maria do Carmo. Educar pela pesquisa: espaço de transformação e avanço na formação do professor de Ciências. [s.l.] Tese (Doutorado em Educação) - Faculdade de Educação, Pontifícia Universidade Católica do Rio Grande do Sul, 2000.

GARRIDO, Elsa; CASTRO, Ruth de; CARVALHO, Anna Maria Pessoa de. El papel de las actividades en la construcción del conocimiento en clase. Investigación en la escuela, n. 23, p. 61-70, 1995. 
GIL PEREZ, Daniel; CASTRO, Pablo Valdés. La orientacion de las practicas de laboratorio como investigación: un ejemplo ilustrativo. Enseñanza de las Ciencias, v. 14, n. 2, p. 155$163,1996$.

GOHN, Maria da Glória. Educação não-formal, participação da sociedade civil e estruturas colegiadas nas escolas. Ensaio - Avaliação e Políticas Públicas em Educação, v. 14, n. 50, p. 27-38, 2006.

JACOBUCCI, Daniela Franco Ccarvalho. Contribuições dos espaços não formais de educação para a formação da cultura científica. Em Extensão, v. 7, n. 1, p. 55-66, 2008.

JIMENEZ-ALEIXANDRE, María Pilar; FERNANDEZ-LOPEZ, Luis. What are authentic practices? Analysis of students' generated projects in secondary school. In: ANNUAL CONFERENCE OF THE NATIONAL ASSOCIATION OF RESEARCH IN SCIENCE TEACHING (NARST), Philadelphia, PA, march, 2010. Anais... Philadelphia, PA: Elsevier Saunders, 2010.

KRASILCHIK, Myriam. Prática de ensino de biologia. São Paulo, SP: EdUSP, 2005.

LOBATO, Anderson Cezar. A abordagem do efeito estufa nos livros de química: uma análise crítica. [62 f.]: Monografia de especialização apresentada à Universidade Federal de Minas Gerais Belo Horizonte, 2007, CECIERJ.

LÜCK, Heloísa. Pedagogia interdisciplinar: fundamentos teórico-metodológicos. $5^{\mathrm{a}}$. ed. Petrópolis, RJ: Vozes, 1995.

MALDANER, Otavio Aloisio. Formação Inicial e Continuada de professores de química: Professores/Pesquisadores. Ijuí, RS: Unijuí, 2006.

MARANDINO, Martha.; SELLES, Sandra Escovedo; FERREIRA, Márcia Serra. Ensino de biologia: histórias e práticas em diferentes espaços educativos. São Paulo, SP: Cortez, 2009.

MAYRING, Philipp. Einführung in die qualitative Sozialforschung [Introdução à pesquisa social qualitativa]. $5^{\mathrm{a}}$. ed. Weinheim: Beltz, 2002.

MENEZES, Luiz Carlos de. Formação continuada de professores de ciências no contexto ibero-americano. $2^{\text {a }}$. ed. São Paulo: Autores Associados/NUPES, 1996.

OLIVEIRA, Christian Dennys Monteiro de; ASSIS, Raimundo Jucier Sousa de. Travessias da aula em campo na geografia escolar: a necessidade convertida para além da fábula.

Educação e Pesquisa, v. 35, n. 1, p. 195-209, 2009.

MOREIRA, Marco Antonio. Uma abordagem cognitivista ao ensino de física. Porto Alegre - RS: Editora da Universidade, 1983.

NEVES, José Luiz. Pesquisa qualitativa: características, usos e possibilidades. Caderno de Pesquisa em Administração, v. 1, n. 3, p. 1-5, 1996. 
NEVES, Ricardo Fereira das; CARNEIRO-LEÃO, Ana Maria dos Anjos; FERREIRA, Helaine Sivini. A Interação do ciclo da experiência de Kelly com o Círculo Hermenêutico-Dialético para a Construção de Conceitos de Biologia. Ciência e Educação, v. 18, n.2, p. 335-352, 2012.

NUÑEZ, Isauro Beltrán; RAMALHO, Betânia Leite; UEHARA, Fabia Maria Gomes. As teorias implícitas sobre a aprendizagem de professores que ensinam Ciências Naturais e futuros professores em formação: a formação faz diferença? Revista Ciências \& Cognição, v. 14, n. 3, p. 39-61, 2009.

OLIVEIRA, Carla Marques Alvarenga de. O que se fala e se escreve nas aulas de ciências?. In: CARVALHO, Anna Maria Pessoa de (Org.). Ensino de ciências por investigação. São Paulo: Cengage Learning, 2013, p. 63-75.

PÉREZ ECHEVERRÍA, María Del Puy; POZO, Juan Ignacio. Aprender a resolver problemas e resolver problemas para aprender. In: POZO, J. I. (Ed.). A solução de problemas. Porto Alegre - RS: Artes Médicas, 1998, p. 13-40.

PERÉZ, Geraldo. Prática reflexiva do professor de matemática. In: BICUDO, Maria Aparecida Viggiani; BORBA, Marcelo (Eds.). Educação matemática: pesquisa em movimento. São Paulo, SP: Cortez, 2004. p. 344.

PIMENTA, Selma Garrido. Formação de professores: identidade e saberes da docência. In: PIMENTA, Selma Garrido. (Ed.). Saberes pedagógicos e atividade docente. $8^{\mathrm{a}}$. ed. São Paulo, SP: Cortez, 2012. p. 304.

POZO, Juan Ignacio. A solução de problemas. Porto Alegre, RS: Artmed, 1998.

POZO, Juan Ignacio; CRESPO, Miguel Angél. A aprendizagem e o ensino de ciências: do conhecimento cotidiano ao conhecimento científico. $5^{\mathrm{a}}$. ed. Porto Alegre, RS: Artmed, 2009.

POZO, Juan Ignacio; PÉREZ ECHEVERRÍA, María Del Puy. La solución de problemas. Madri: Santillana, 1994.

PEREZ ECHEVERRÍA, María Del Puy; POZO, Juan Ignacio (1994) Aprender a resolver porblemas e resolver problemas para aprender. In: POZO, Juan Ignacio (Org.). A solução de problemas. Porto Alegre: Artes Médicas, 1998.

REGO, Teresa Cristina. Vygotsky: uma perspectiva histórico-cultural da educação. Petrópolis: Vozes, 1995.

ROCHA, Sônia Cláudia Barroso da; FACHÍN-TERÁN, Augusto. O uso dos espaços não formais como estratégia para o Ensino de Ciências. Manaus: UEA Edições, 2010.

SANTOS, Wildson Luiz Pereira dos; MORTIMER, Eduardo Fleury. Uma análise de pressupostos teóricos da abordagem CTS (Ciência-Tecnologia-Sociedade) no contexto da 
educação brasileira. Ensaio - Pesquisa em Educação em Ciências, v. 2, n. 2, p. 133-162, 2000.

SASSERON, Lúcia Helena; CARVALHO, Anna Maria Pessoa de. Alfabetização Científica: uma revisão bibliográfica. Investigações em Ensino de Ciências, v. 16, n. 1, p. 59-77, 2011.

SCHÖN, Donald. Educando o profissional reflexivo: um novo design para o ensino e a aprendizagem. $1^{\mathrm{a}}$. ed. Porto Alegre, RS: Artmed, 2003.

SHULMAN, Lee. Knowledge and Teaching: Foundations of the New Reform. Harvard Educational Review, v. 57, n. 1, p. 1-22, 1987.

SILVA, Maria Helena Santos.; DUARTE, Maria da Conceição. Diário de aula na formação de professores reflexivos: resultados de uma experiência com professores estagiários de Biologia/Geologia. Revista Brasileira de Pesquisa em Educação em Ciências, v. 1, n. 2, p. 73-84, 2002.

TARDIF, Maurice. Saberes docentes e formação profissional. $4^{\mathrm{a}}$. ed. Petrópolis, RJ: Vozes, 2002.

TARDIF, Maurice. Saberes docentes e formação profissional. $13^{\mathrm{a}}$. ed. Petrópolis, RJ: Vozes, 2012.

TOBALDINI, Bárbara Grace.; FERRAZ, Daniela Frigo. A contribuição da abordagem dos temas sociais contemporâneos na perspectiva de acadêmicos em formação inicial. In: VIII ENPEC - ENCONTRO NACIONAL DE PESQUISA EM EDUCAÇÃO EM CIÊNCIAS, Universidade Estadual de Campinas, 05 a 09 de dezembro. Anais... Campinas, SP: ABRAPEC, 2011.

TROJAN, Rose Meri. Teoria e prática na formação docente: estudo das políticas educacionais brasileiras e cubanas. Práxis Educativa, v. 3, n. 1, p. 29-42, 2008.

TROPIA, Guilherme. Relações dos alunos com o aprender no ensino de Biologia por atividades investigativas. Dissertação de Mestrado apresentada à Universidade Federal de Santa Catarina, 2009.

VERCEZE, Rosa Maria Aparecida Nechi; SILVINO, Eliziane França Moreira. O livro didático e suas implicações na prática do professor nas escolas públicas de Guajará-Mirim. Práxis Educacional, v. 4, n. 4, p. 83-102, 2008.

VYGOTSKY, Lev Semenovitch. A Formação Social da Mente. São Paulo: Martins Fontes, 1984.

VYGOTSKY, Lev Semenovitch. A formação social da mente. Rio de Janeiro, RJ: Martins Fontes, 1996. 
VYGOTSKY, Lev Semenovitch. A formação social da mente: o desenvolvimento dos processos psicológicos superiores. São Paulo, SP: Martins Fontes, 1989.

VYGOTSKY, Lev Semenovitch. Aprendizagem e desenvolvimento intelectual na idade escolar. In: VYGOTSKY, Lev Semenovitch. Linguagem, desenvolvimento e aprendizagem. $2^{a}$. ed. São Paulo, SP: Ícone, 1988. p. 103-117.

VYGOTSKY, Lev Semenovitch. Obras escogidas: problemas de psicologia geral. Madrid: Rogar Fuenlabrada, 1982.

VYGOTSKY, Lev Semenovitch. VYGOTSKY, L. S. $2^{\mathrm{a}}$. ed. São Paulo, SP: Martins Fontes, 2007.

WELLS, Gordon. Dialogic inquiry: Towards a sociocultural practice and theory of education. Cambridge: Cambridge University Press, 1999.

XAVIER, Odiva Silva.; FERNANDES, Rosana César de Arruda. A Aula em espaços nãoconvencionais. In: Aula: gênese, dimensões, princípios e práticas. $1^{\mathrm{a}}$. ed. Campinas, SP: Papirus Editora, 2007. p. 298.

ZANELLA, Andréa Vieira. Zona de desenvolvimento proximal: análise teórica de um conceito em algumas situações variadas. Temas em Psicologia, v. 2, n. 2, p. 97-110, 1995.

Recebido em: 29/03/2015 Aprovado em: 27/07/2015

Universidade do Estado de Santa Catarina - UDESC Programa de Pós-Graduação em Educação - PPGE Revista Linhas Volume 17 - Número 34 - Ano 2016 revistalinhas@gmail.com 